\title{
Assessing the Energy Efficiency improvement for hospitals in Egypt using building simulation modeling
}

\author{
Micheal A. William, Aly M. El-Haridi, Ahmed A. Hanafy, \\ and Abd El-Hamid A. El-Sayed \\ Mechanical Engineering Department, College of Engineering \& Technology, \\ Arab Academy for Science, Technology \& Maritime Transport, Alexandria, Egypt \\ E-mail: $\underline{\text { mikwilliam2@gmail.com }}$
}

\begin{abstract}
:
Energy Consumption in Egypt's buildings has increased considerably with the growing need to achieve thermal comfort conditions inside buildings. The continuing increases in both residential and commercial buildings require an increase in power generation meeting the new demand. Due to the increase of HVAC systems operating hours, energy consumption in buildings is increasing yearly. It is desirable to minimize energy consumption and to promote the use of renewable energy resources, saving the earth from global warming effects and the depletion of the ozone layer.

In hot humid climatic regions, high temperatures with high humidity levels result in human discomfort leading to high HVAC energy consumption. In order to understand the energy performance in Egyptian hospitals as it has special requirements and massive energy consumption of HVAC equipment, medical equipment, lighting and infection control systems a hospital located in Alexandria, Egypt was chosen as a case study. The study aims to investigate the energy consumption in Egyptian hospitals and to evaluate the energy-saving efficiency of the existing building. A model for under construction hospital was created using DesignBuilder simulation tool. The model was validated based on the construction and mechanical consultants' data based on the initial model energy consumption then the model was retrofitted firstly to the latest design conditions and weather file data based on ASHRAE and NREL recommendations. Energy efficient techniques affecting the cooling load, annual HVAC energy consumption and total building energy were investigated. The study provides information for energy efficiency improvements in Alexandria, Egypt hospitals helping designers managing energy in buildings reducing the energy consumption sufficiently. The new energy model was simulated resulting in about 55\% in HVAC consumption and approximately $59 \%$ for whole building energy consumption.
\end{abstract}

This paper recommends a new energy model for future hospitals in Alexandria, Egypt improving the energy efficiency in buildings.

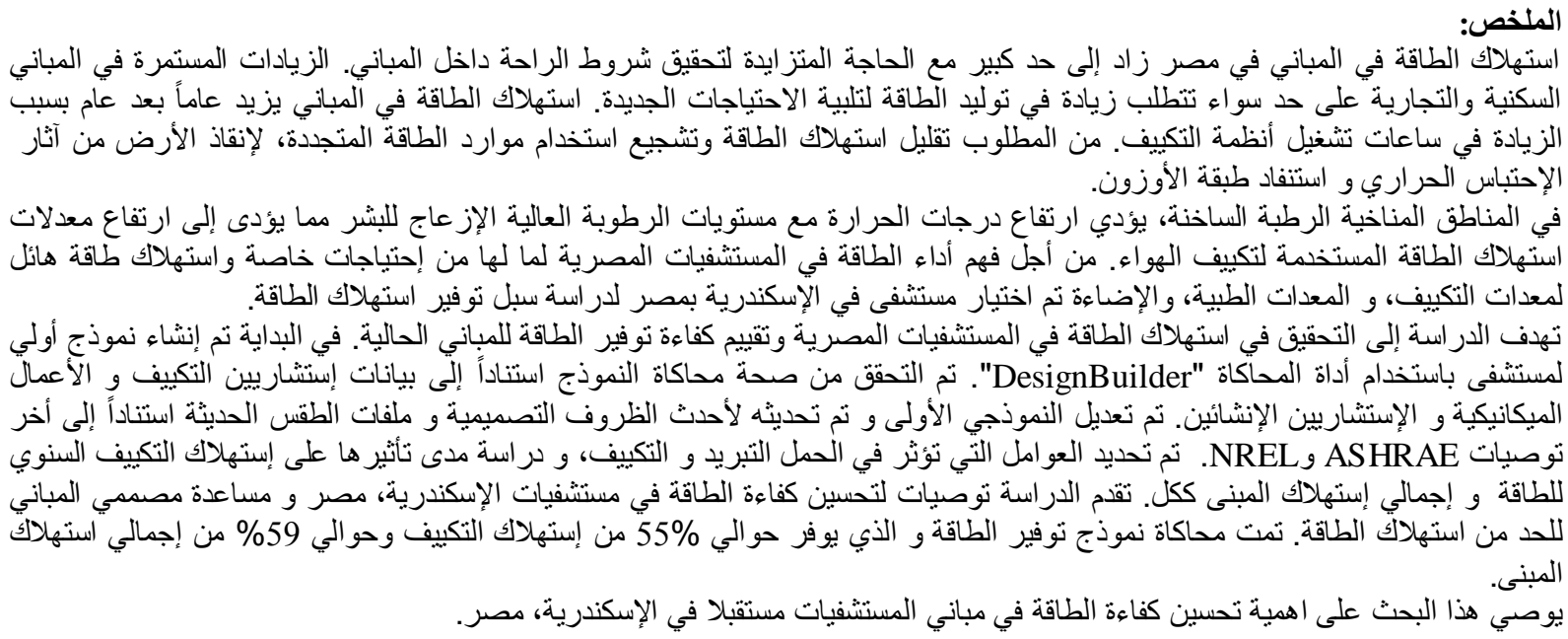

Keywords: Energy management; Energy in Buildings; Energy Saving in hot humid climate. 


\section{1- Introduction}

Egypt's installed capacity in the energy sector has increased due to the increase in domestic consumption. About 95\% of Egypt's total energy consumption is fuelled by oil and natural gas, with the remainder being fuelled by coal, hydroelectric and renewable energies [1]. As a result, the Egyptian government stimulates the research in energy management and saving. In commercial buildings generally, HVAC consumes up to $56 \%$ of the total energy used in the building as illustrated in Figure 1 [2].

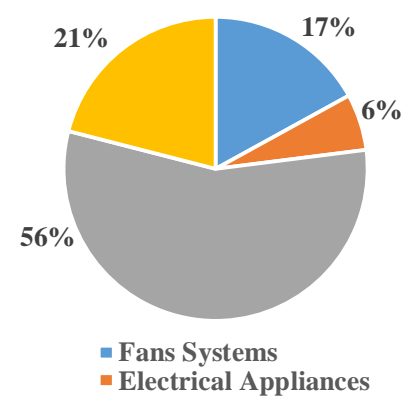

Figure (1): Building Energy Consumption in Egypt (2008) [2]

Therefore, designing an energy efficient system providing thermal comfort and Indoor air quality (IAQ) is a must. As a result of global warming and climate change, HVAC energy consumption will rise too. Studying the energy efficiency in hospitals, especially, was because hospitals consume huge consumption compared to other commercial activities due to the 24 hours per 7 days availability. Designing an energy efficient system in healthcare facilities needs an epistemology of the factors affecting energy optimization without compromising health safety or care effectiveness to occupants.

About $3 \mathrm{kWh}$ electrical energy is required for $1 \mathrm{kWh}$ to be distributed to consumers as the electrical efficiency is $33 \%$ approximately [3]. As shown in Figure (2) [4], about $16.8 \%$ of the consumed energy was by commercial and utility sectors.

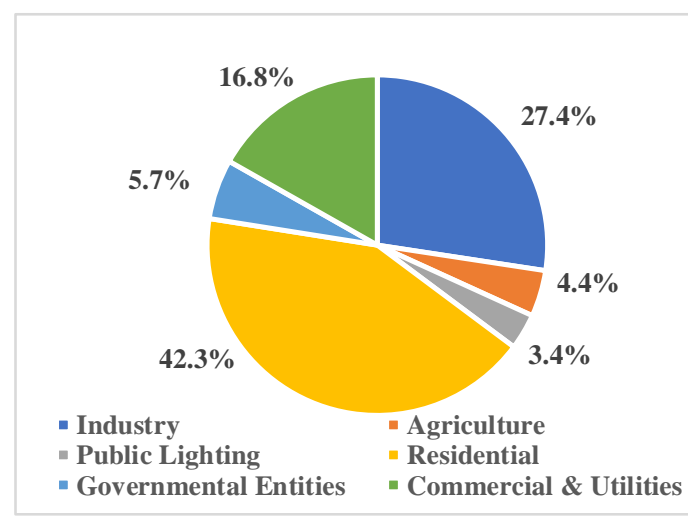

Figure (2): Energy Consumption in Egypt by Utility (2016/2017) [4]

As previous research by the Spanish Institute for Energy Diversification and Saving (IDAE), stated that $\mathrm{CO}_{2}$ emissions are highly affected by building sector, especially, the healthcare system that achieved the highest energy intensity, associated with the different activities it involves. [5] González et al. [6] stated that energy management and renewable energy globally reduce $\mathrm{CO}_{2}$ emissions in both energy production processes and in actions involving the improvement of energy efficiency. Hoyt et al. [7] found studied increasing the cooling setpoint from $22{ }^{\circ} \mathrm{C}$ to $25{ }^{\circ} \mathrm{C}$, approximately $29 \%$ energy savings were achieved. $\mathrm{He}$ also mentioned that in hot climates increasing cooling set points will be more efficient. Ahn et al. [8] found using simulation tools that LED lightings when used with control strategy reduces energy consumption 20 $40 \%$ of the total energy consumption in buildings. Jenkins et al. [9] studied for a typical 6 office building, savings of lighting reached annual savings of 56-62\% and a reduction in $\mathrm{CO}_{2}$ emissions of nearly 3 tonnes are predicted by changing the lighting type. Sabry et al. [10] discussed using DesignBuilder simulation tool the effect of walls and roof insulation on energy consumption and $\mathrm{CO}_{2}$ reduction in residential buildings in Egypt. Reduction of about $40 \%$ of the energy consumed by the HVAC resulted when using thermal insulation in the walls and roofs, such savings represent a significant operating cost reduction. Karmany et al. [11] stated that countries sustainable development and green building assessment systems have a direct relationship. She also stated the benefits of sustainable design and construction through a green building assessment system have paybacks on three stages; (1) human level benefits, (2) Country-level benefits, and (3) global level benefits. Dutta et al. [12] study, shows the effect of different glazing types on the reduction of both cooling load and energy. The paper gives an idea of the selection of window glazing from commercially available glasses so that building managers can select the suitable type of glass from the 
commercial market based on research outcome to reduce the energy consumption of the building.

Elharidi et al. [13] discussed that different systems efficiencies (HVAC, lights, equipment) and occupant behavior (e.g. use of systems, temperatures) were also identified as significant factors in energy savings, each with the potential of around 30\% saving compared to current typical offices. Possible policy measures to promote energy efficient systems and energy conscious behavior are proposed which together can reduce the energy demand of typical offices by $50 \%$. Yusoff et al. [14] stated that buildings consume a huge percentage of annual energy consumption such as in HVAC, lighting and electrical equipment. The paper also mentioned the effect of efforts done by governmental and nongovernmental agencies which helps improving buildings energy efficiency through many strategies and technologies. AbdulRazek [15] developing tools for Energy Efficiency for Lebanese buildings to compare the performance of the current building with the local and international standards to set energy efficiency benchmarks that compare the consumption with the best practices. He also mentioned that the average annual consumption in hospitals according to ANSI/ASHRAE/USGBC/IES Standards 189.1 was $200.37 \mathrm{kWh} / \mathrm{m}^{2}$.

The review shows that energy consumption is a major study that governments invest in. Since a lack of research in Energy savings in hot humid climate regions, a hospital in Egypt was chosen as a case study.

\section{2- Methodology}

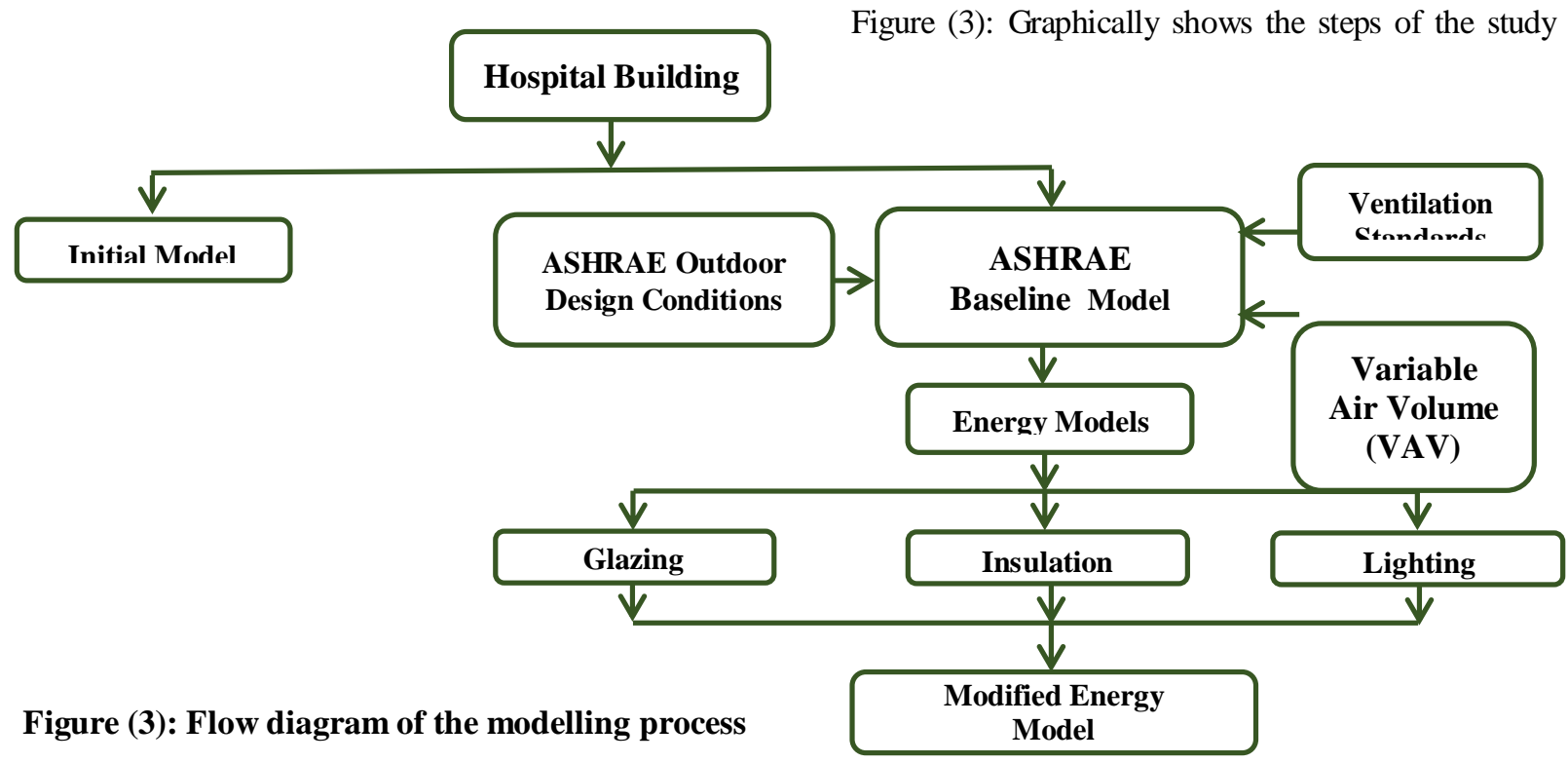

The study started with a market survey on the values of different parameters used in cooling load calculations by most Egyptian HVAC designers and consultants in Egypt. Based on the survey, a hospital building located in Alexandria, Egypt was chosen for the case study. To account for energy interactions between building subsystems, DesignBuilder V4.5 (2015) was used to build the initial model which was then validated based on the Egyptian construction and mechanical consultants. The energy performance of the initial and other models of the building were simulated to verify that energy savings are achievable. DesignBuilder was chosen as it is an interface to the EnergyPlus which is developed by U.S. Department of Energy's (DOE) Building Technologies Office (BTO) as a detailed building simulation tool. DesignBuilder computes building energy use based on the interactions between the climate, building envelope, internal gains, and HVAC systems. The following steps were used on Design builder in the study:

1. Building the architectural characteristics of the hospital initial model, defining each space in the model.

2. Creating an ASHRAE baseline energy model for Alexandria, Egypt using the recommended ASHRAE design conditions 2017.

3. Applying ASHRAE standards (62.1-2016, 1702017, 90.1-2016), AIA hospitals and healthcare facilities and Green Guide for health care facilities to the baseline model.

4. Simulating the initial, ASHRAE baseline and energy models to show that $50 \%$ (or greater in hot humid climates) energy savings are achieved when the energy design measures are applied to the ASHRAE baseline model.

Figure (3): Graphically shows the steps of the study 


\section{Case Study Analysis}

The case study is a hospital building located in Alexandria, Egypt.

\subsection{Description of the case study}

In this study a hospital in Alexandria, Egypt was chosen. The building consists of five floors with a total area of about $10,000 \mathrm{~m}^{2}$ as shown in Figure (4).

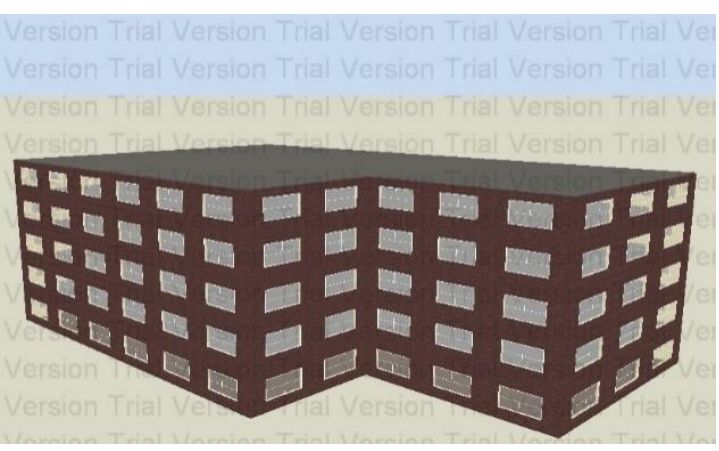

Figure (4): Hospital Overview

Spaces in the hospital were assigned to different space types shown in Table (1).

\subsection{Outdoor Design Condition (ODC)}

Right-sizing is one of the important processes in terms of appropriate energy use in buildings. Outdoor design conditions in Alexandria, Egypt (DBT $40{ }^{\circ} \mathrm{C}$, WBT $30^{\circ} \mathrm{C}$ ) as Table (2) which is estimated by most HVAC designers, leading to oversizing of HVAC systems eventually resulting in waste of energy. Retrofitting to the recommended ventilation rates and the ASHRAE Outdoor Design Conditions 2017 (DBT $33.2{ }^{\circ} \mathrm{C}$, WBT $22.4{ }^{\circ} \mathrm{C}$ ) shown in Table (2) [16] and weather file data of Alexandria, Egypt as Figure (5) provided by Energy Plus [17], is recommended.
Table (1): Conditioned Area Percentage

\begin{tabular}{|c|c|c|}
\hline Zone & \multirow{2}{*}{$\operatorname{Area}\left(\mathbf{m}^{2}\right)$} & \multirow{2}{*}{ Area \% } \\
\hline Space Type & & \\
\hline Trauma & 46 & $0.54 \%$ \\
\hline Triage & 16 & $0.19 \%$ \\
\hline Examination/ Treatment & 301 & $3.55 \%$ \\
\hline Staff Lounge & 131 & $1.54 \%$ \\
\hline Offices & 243 & $2.86 \%$ \\
\hline $\begin{array}{l}\text { Imaging Diagnosing } \\
\text { Rooms }\end{array}$ & 228 & $2.68 \%$ \\
\hline IT Room & 50 & $0.60 \%$ \\
\hline Corridor/ Waiting Area & 3,774 & $44.30 \%$ \\
\hline Pharmacy & 68 & $0.80 \%$ \\
\hline Shop & 27 & $0.32 \%$ \\
\hline Clinics & 331 & $3.89 \%$ \\
\hline Conference room & 130 & $1.53 \%$ \\
\hline Sampling/ Laboratories & 48 & $0.57 \%$ \\
\hline Physical Therapy & 133 & $1.56 \%$ \\
\hline Operating Rooms & 351 & $4.12 \%$ \\
\hline Delivery Rooms & 32 & $0.38 \%$ \\
\hline Recovery Rooms & 83 & $0.98 \%$ \\
\hline Post-Surgery Rooms & 37 & $0.44 \%$ \\
\hline NICU & 129 & $1.52 \%$ \\
\hline ICU & 226 & $2.66 \%$ \\
\hline Bedwards & 1,728 & $20.20 \%$ \\
\hline Living Rooms & 248 & $2.92 \%$ \\
\hline Isolation Rooms & 58 & $0.69 \%$ \\
\hline Doctors Rooms & 99 & $1.18 \%$ \\
\hline Total Conditioned Area & 8,517 & $100 \%$ \\
\hline
\end{tabular}

Table (2) Climatic design conditions of Alexandria

\begin{tabular}{|c|c|c|c|}
\hline \multicolumn{2}{|c|}{ Initial Model* } & \multicolumn{2}{|c|}{$\begin{array}{c}\text { ASHRAE Baseline Model } \\
{[16]}\end{array}$} \\
\hline $\begin{array}{c}\text { DBT } \\
{ }^{\circ} \mathrm{C}\end{array}$ & $\mathrm{WBT}^{\circ} \mathrm{C}$ & $\mathrm{DBT}^{\circ} \mathrm{C}$ & $\mathrm{WBT}^{\circ} \mathrm{C}$ \\
\hline 40 & 30 & 33.2 & 22.4 \\
\hline
\end{tabular}

*Value by most HVAC designers 


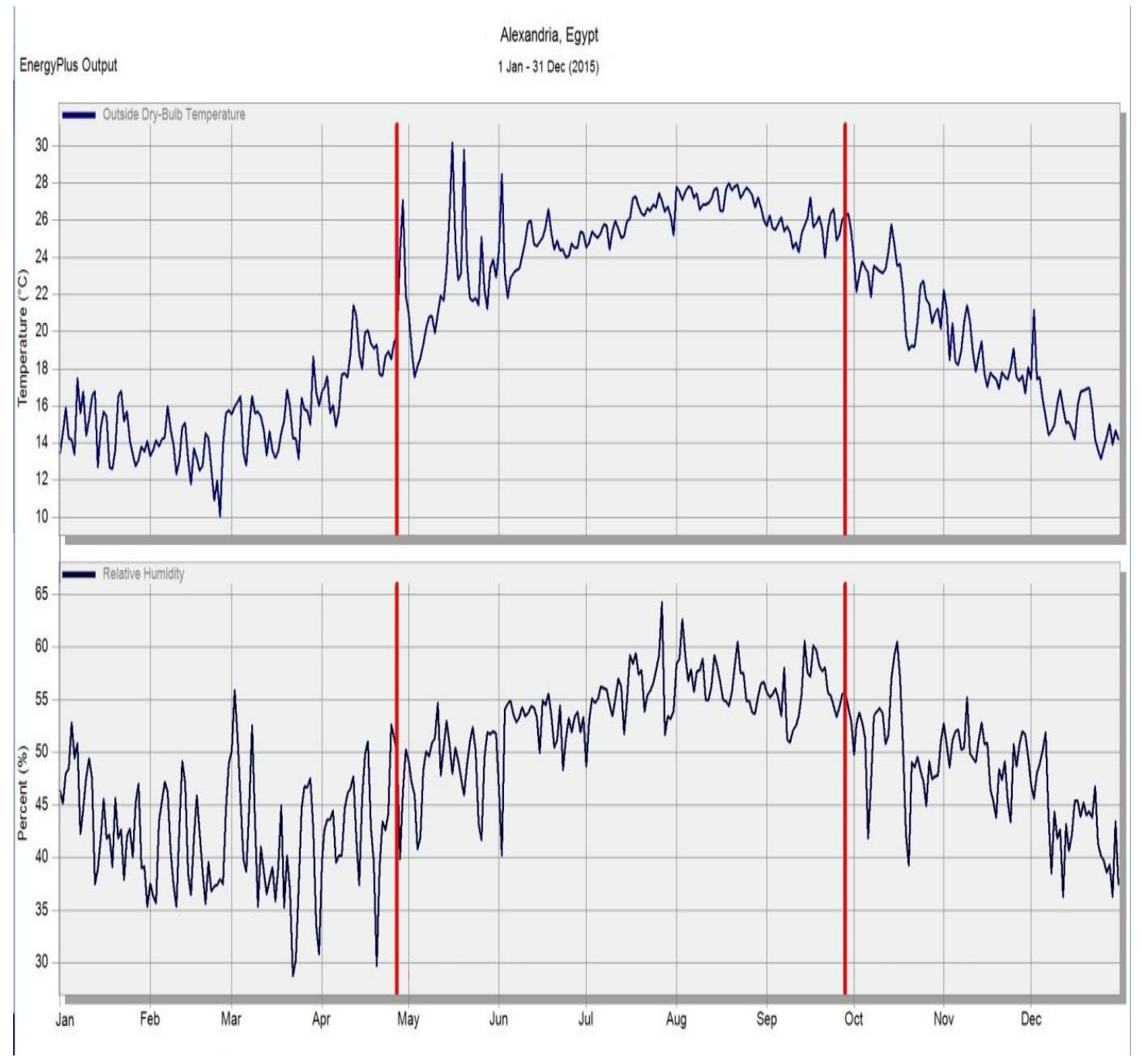

Figure (5): Alexandria, Egypt weather file data [17]

\subsection{Building Envelop}

\subsubsection{Exterior walls}

The hospital ASHRAE baseline walls were constructed as Egyptian building market construction. The walls were then insulated using Polyurethane foam [24] in the Modified model as recommended by the Housing and Building National Research Center (HRBC) and Egyptian construction consultants. Wall layers of both baseline and modified model are tabulated in Table (3).

\subsubsection{Roof Construction Design}

The baseline model roof is the available in the existing building and the modified model roof construction is as recommended by Housing and Building National Research Center (HRBC) and Egyptian construction consultants tabulated in Table (3).

\subsubsection{Glazing}

The glazing type of both models are described in Table (3) with the Overall heat transfer coefficient (U) and the Solar heat gain coefficient (SHGC) of each. 
Table (3): Building construction description

\begin{tabular}{|c|c|c|}
\hline Model & Initial \& Baseline & Modified Energy Model \\
\hline \multicolumn{3}{|l|}{ Exterior walls } \\
\hline Construction & $\begin{array}{l}200 \mathrm{~mm} \text { Common Brick + } \\
50 \mathrm{~mm} \text { Cement Plaster }\end{array}$ & $\begin{array}{c}200 \mathrm{~mm} \text { Common Brick + } \\
50 \mathrm{~mm} \text { Cement Plaster }+ \\
25 \mathrm{~mm} \text { Polyurethane [24] }\end{array}$ \\
\hline U-factor $\left(\mathrm{W} / \mathrm{m}^{2}{ }^{\circ} \mathrm{C}\right)$ & 1.924 & 0.708 \\
\hline \multicolumn{3}{|l|}{ Roof } \\
\hline Construction & $\begin{array}{c}20 \mathrm{~mm} \text { Cement Plaster + } \\
180 \mathrm{~mm} \text { Hurdy Block + } \\
20 \mathrm{~mm} \text { Moisture Insulation + } \\
50 \mathrm{~mm} \text { Sand Layer + } \\
25 \mathrm{~mm} \text { Mortar Layer + } \\
30 \mathrm{~mm} \text { Tiles }\end{array}$ & $\begin{array}{c}20 \mathrm{~mm} \text { Cement Plaster + } \\
180 \mathrm{~mm} \text { Hurdy Block + } \\
20 \mathrm{~mm} \text { Moisture Insulation + } \\
50 \mathrm{~mm} \text { Sand Layer + } \\
25 \mathrm{~mm} \text { Polyurethane [24] + } \\
25 \mathrm{~mm} \text { Mortar Layer + } \\
30 \mathrm{~mm} \text { Tiles }\end{array}$ \\
\hline U-factor $\left(\mathrm{W} / \mathrm{m}^{2}{ }^{\circ} \mathrm{C}\right)$ & 2.27 & 0.75 \\
\hline \multicolumn{3}{|l|}{ Window } \\
\hline Glazing Type & $6 \mathrm{~mm}$ Single Clear Glass & $\begin{array}{c}6 \mathrm{~mm} \text { Double Reflective } \\
\text { Low-e Coloured Glass } \\
6 \mathrm{~mm} \text { Air gap }\end{array}$ \\
\hline $\mathrm{U}$-factor $\left(\mathrm{W} / \mathrm{m}^{2}{ }^{\circ} \mathrm{C}\right)$ & 5.778 & 2.235 \\
\hline SHGC & 0.819 & 0.15 \\
\hline
\end{tabular}

\subsection{Ventilation}

Ventilation rates tabulated in Table (4) were based on room type according to the AIA Guidelines for Design and Construction of Health Care Facilities
[18], ANSI/ASHRAE/ASHE Standard 62.1-2016 (ASHRAE 2016) [19], ANSI/ ASHRAE/ASHE Standard 170-2017 (ASHRAE 2017) [20]. 
Table (4): Recommended Ventilation Rates for hospitals [18][19][20]

\begin{tabular}{|l|c|c|c|}
\hline \multicolumn{1}{|c|}{ Room Type } & $\begin{array}{c}\text { Ventilation per Person } \\
(\mathbf{L} / \mathbf{s} \text { per person) }\end{array}$ & $\begin{array}{c}\text { Ventilation per Area } \\
\left(\mathbf{L} / \mathbf{s}-\mathbf{~ m}^{2}\right)\end{array}$ & $\begin{array}{c}\text { Minimum Total } \\
\text { ACH }\end{array}$ \\
\hline Anaesthesia gas storage & - & 0.61 & 8 \\
\hline Examination/ Treatment Rooms & 2.5 & 0.3 & 6 \\
\hline Trauma & 2.5 & 0.3 & 15 \\
\hline Triage & - & - & 12 \\
\hline Operating Suite/Delivery Rooms & - & - & 20 \\
\hline Imaging Diagnosing & 2.5 & 0.3 & - \\
\hline Offices & 2.5 & 0.3 & 6 \\
\hline Bed wards & 2.5 & 0.3 & 4 \\
\hline Pharmacy & 2.5 & 0.9 & 6 \\
\hline Physical Therapy & 9.4 & 0.3 & 6 \\
\hline Clinics & 2.5 & 0.3 & - \\
\hline Corridors/Waiting & - & 0.3 & 6 \\
\hline Recovery/ ICU & - & - & - \\
\hline Conference & 2.5 & 0.3 & \\
\hline
\end{tabular}

\section{Internal Loads}

\subsection{Occupant Density}

Occupancy density values by room type were defined according to AIA Guidelines for Design and Construction of Health Care Facilities (2006) [18], and ASHRAE Standard 62.1 (2016) [19] in Table (5).

\subsection{Interior Lighting}

Lighting power density (LPD) $\left.\left(40 \mathrm{~W} / \mathrm{m}^{2}\right)\right)$ assumed by most Egyptian HVAC designers using Building Area Method in Table (5). The new Modified Model LPD is Lighting Emitting Diodes (LED) with about $\left(7.5 \mathrm{~W} / \mathrm{m}^{2}\right)$ [21].

\subsection{Plug Loads}

Plug loads are energy used by equipment that is usually plugged into an outlet typically including office and general miscellaneous equipment, computers and others and they are tough to be estimated. Plug load densities tabulated in Table (5) were recommended by the Green Guide for Health Care: Best Practices for Creating HighPerformance Healing Environments, Version 2.2 (GGHC) [22] and ASHRAE Standard 90.1-2016 [23] and they remain constant in all simulated models. 
Table (5): Recommended occupant densities and plug loads of hospitals

\begin{tabular}{|c|c|c|}
\hline Zone & $\begin{array}{l}\text { Occupant Density } \\
\left(\# / 100 \mathrm{~m}^{2}\right) \text { [18] [19] }\end{array}$ & $\begin{array}{c}\text { Plug Loads }\left(\mathrm{W} / \mathrm{m}^{2}\right) \\
{[22][23]}\end{array}$ \\
\hline \multicolumn{3}{|l|}{ Ground Floor } \\
\hline Trauma & 5.38 & 43.06 \\
\hline Triage & 5.38 & 21.53 \\
\hline Examination/ Treatment & 5.38 & 16.15 \\
\hline Staff Lounge & 66.67 & 1.00 \\
\hline Offices & 7.53 & 11.84 \\
\hline Imaging Diagnosing Rooms & 5.38 & 107.64 \\
\hline IT Room & 4 & 10.00 \\
\hline Corridor/ Waiting Area & 32.29 & 1.08 \\
\hline Pharmacy & 10.76 & 10.80 \\
\hline Shop & 8 & 15.00 \\
\hline \multicolumn{3}{|l|}{ 1st Floor } \\
\hline Clinics & 5.38 & 16.15 \\
\hline Conference room & 50 & 10.00 \\
\hline Treatment Rooms & 5.38 & 16.15 \\
\hline Sampling/ Laboratories & 5.38 & 43.06 \\
\hline Offices & 7.53 & 11.84 \\
\hline IT Room & 4 & 10.00 \\
\hline Physical Therapy & 10.76 & 10.80 \\
\hline Corridor/ Waiting Area & 32.29 & 1.08 \\
\hline Imaging Diagnosing Rooms & 5.38 & 107.64 \\
\hline \multicolumn{3}{|l|}{ 2nd Floor } \\
\hline Operating Rooms & 5.38 & 43.06 \\
\hline Delivery Rooms & 5.38 & 43.06 \\
\hline Recovery Rooms & 5.38 & 21.53 \\
\hline Post-Surgery Rooms & 5.38 & 21.53 \\
\hline NICU & 5.38 & 21.53 \\
\hline ICU & 5.38 & 21.53 \\
\hline IT Room & 4 & 10.00 \\
\hline Offices & 7.53 & 11.84 \\
\hline Corridor/ Waiting Area & 32.29 & 1.08 \\
\hline \multicolumn{3}{|l|}{ 3rd Floor } \\
\hline Bedwards & 5.38 & 10.80 \\
\hline Living Rooms & 5.38 & 10.80 \\
\hline Isolation Rooms & 5.38 & 43.06 \\
\hline Doctors Rooms & 5.38 & 10.80 \\
\hline Staff Lounge & 66.67 & 1.00 \\
\hline IT Room & 4 & 10.00 \\
\hline Corridor/ Waiting Area & 32.29 & 1.08 \\
\hline \multicolumn{3}{|l|}{ 4th Floor } \\
\hline Bedwards & 5.38 & 10.80 \\
\hline Living Rooms & 5.38 & 10.80 \\
\hline Isolation Rooms & 5.38 & 43.06 \\
\hline Doctors Rooms & 5.38 & 10.80 \\
\hline Staff Lounge & 66.67 & 1.00 \\
\hline IT Room & 4 & 10.00 \\
\hline Corridor/ Waiting Area & 32.29 & 1.08 \\
\hline
\end{tabular}




\section{Energy use of building initial model}

The building energy use of initial model was divided into three main sectors as shown in Figure (6).

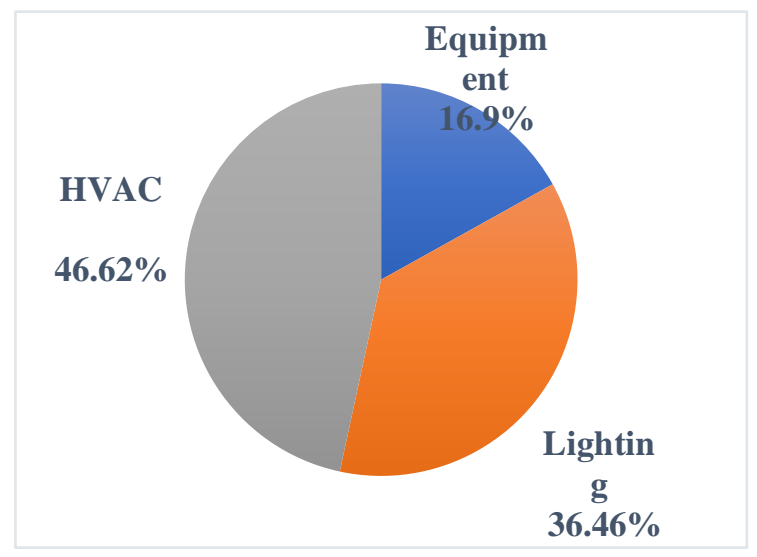

Figure (6): Hospital Initial Model Energy Use

Retrofitting the outdoor design conditions (ODC) from most Egyptian Designers and consultants' data to the ASHRAE outdoor design conditions mentioned in Table (3) with the weather file data of Alexandria, Egypt provided by EnergyPlus [17], and implementing variable air volume (VAV)

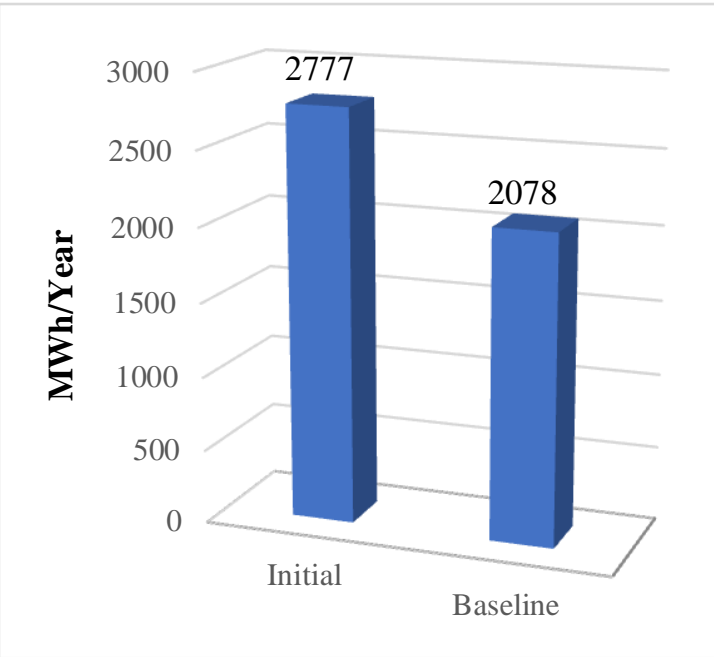

Figure (7): HVAC Energy use due to retrofitting. system showed a significant reduction on HVAC energy use in the building. Figure (7) and (8) show $25.17 \%$ energy saving in HVAC energy consumption.

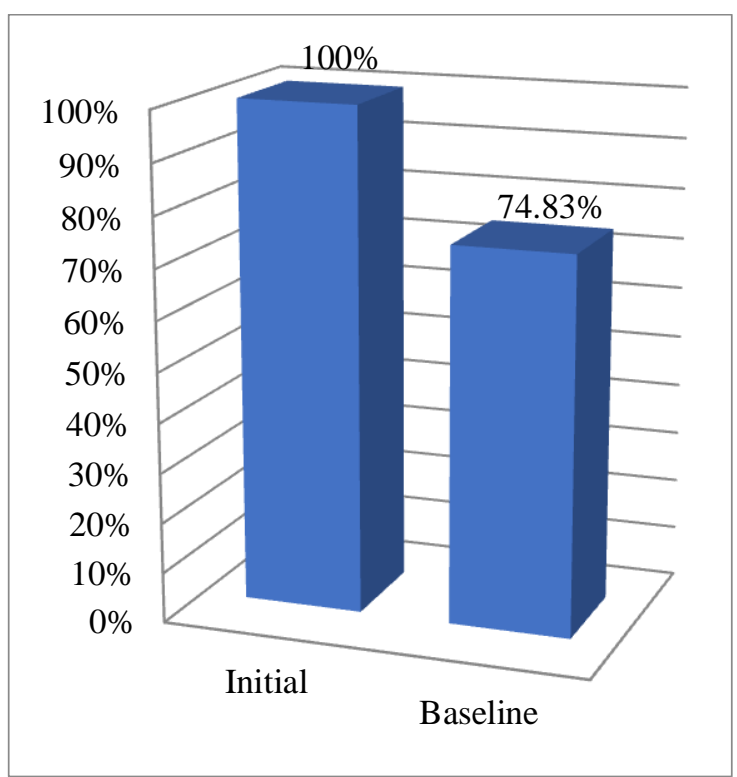

Figure (8): HVAC Energy use percentage due to retrofitting.

The studies were then compared to the ASHRAE Baseline model as a reference.

\section{Results}

In this section, different parameters effect on Energy consumption is illustrated on graphs showing the savings percentage of each.

\subsection{Glazing Model}

Using Double Low-E glazing that has been treated using special metallic oxide covering which produce heat reflective surface while permitting light to pass through it. Reduction of $4.62 \%$ in HVAC Energy consumption was achieved compared to the ASHRAE baseline model shown in Figure (9). 


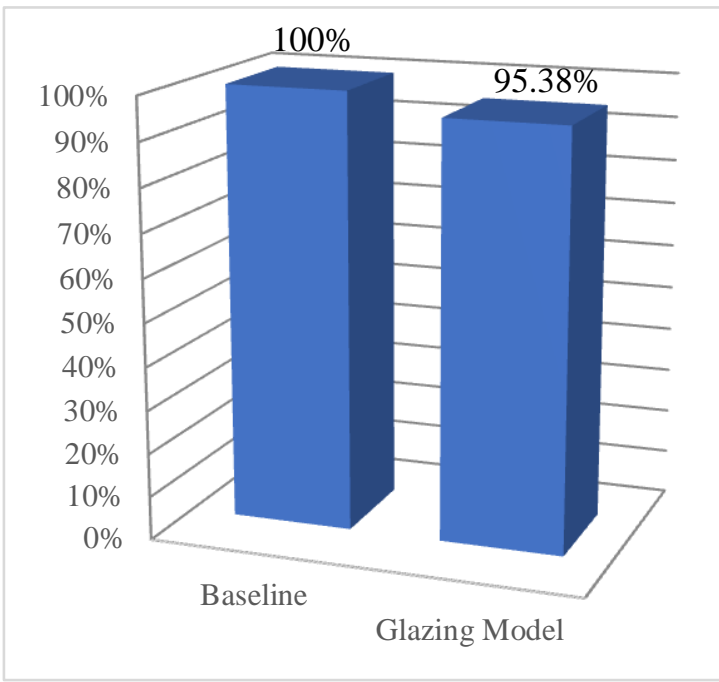

Figure (9): HVAC Energy use due to Glazing

\subsection{Insulation Model}

The energy we use to cool our buildings can be lost without insulations. Insulation helps reducing energy use decreasing both greenhouse

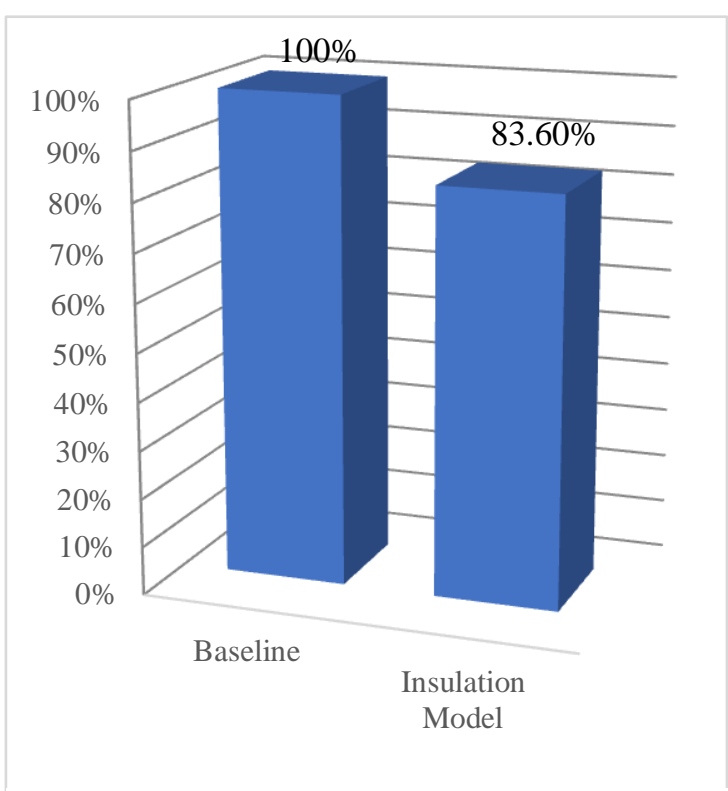

Figure (10): HVAC Energy use due to Insulation

effect and electricity bills. Polyurethane insulations were used in the simulation resulting in about $16.4 \%$ savings in HVAC Energy consumption from the ASHRAE baseline model shown in Figure (10).

\subsection{Lighting Model}

As known that Lighting Emitting Diodes (LED) has lower heat emission than lamps assumed and used by most Egyptian designers.
Figure (11) shows energy savings which reached $21.08 \%$ in HVAC Energy consumption compared to the ASHRAE baseline model.

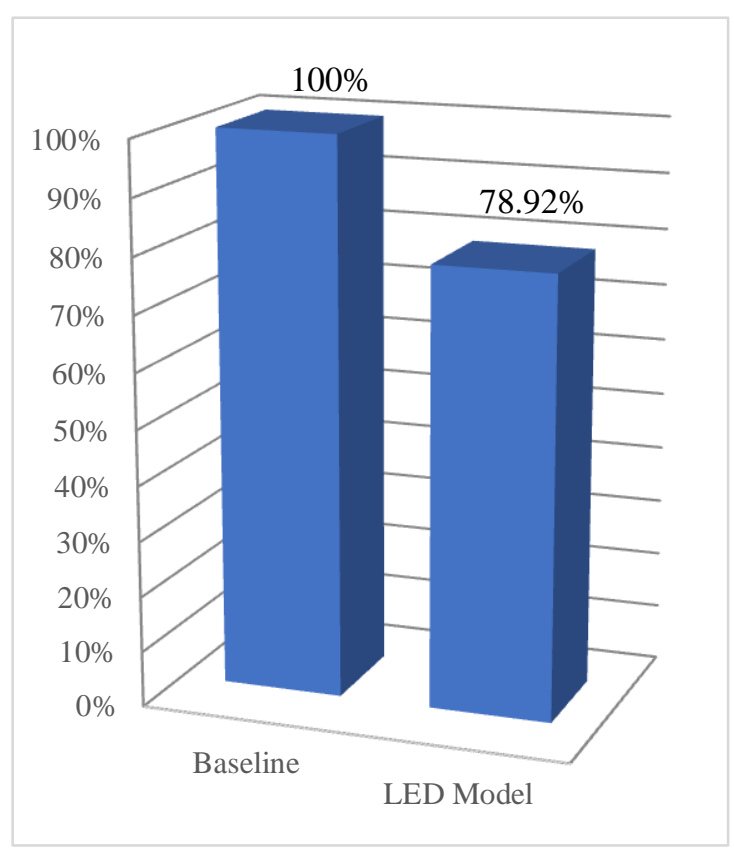

Figure (11): HVAC Energy use due to LED

\subsection{Modified Energy Model}

Combining LED techniques with Low-E double glazing, insulation in walls and roof named as Modified Energy Model resulted in about 55\% savings in HVAC Energy consumption compared to ASHRAE baseline model shown in Figure (12).

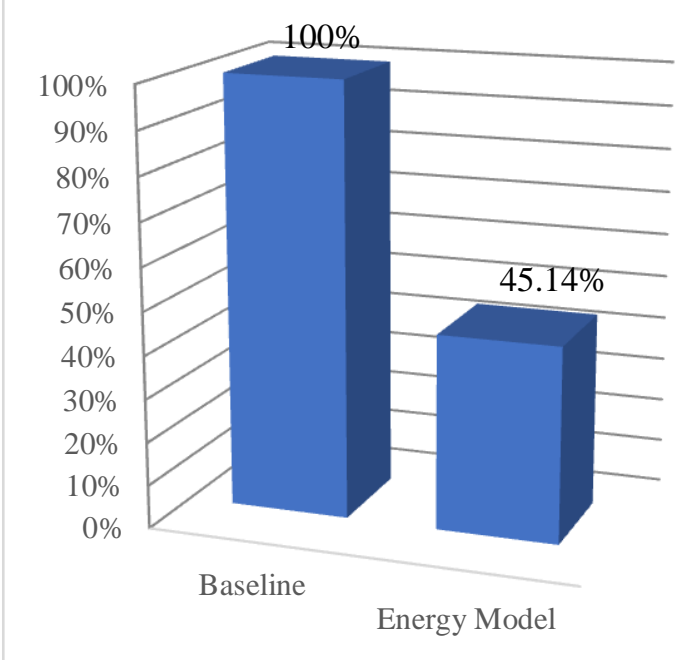

Figure (12): HVAC Energy Use due to the Modified Energy Model 


\subsection{HVAC Energy Saving Parameters}

Figure (13) shows the HVAC energy consumption of the ASHRAE baseline model compared to all other modifications showing the new use percentage of each.

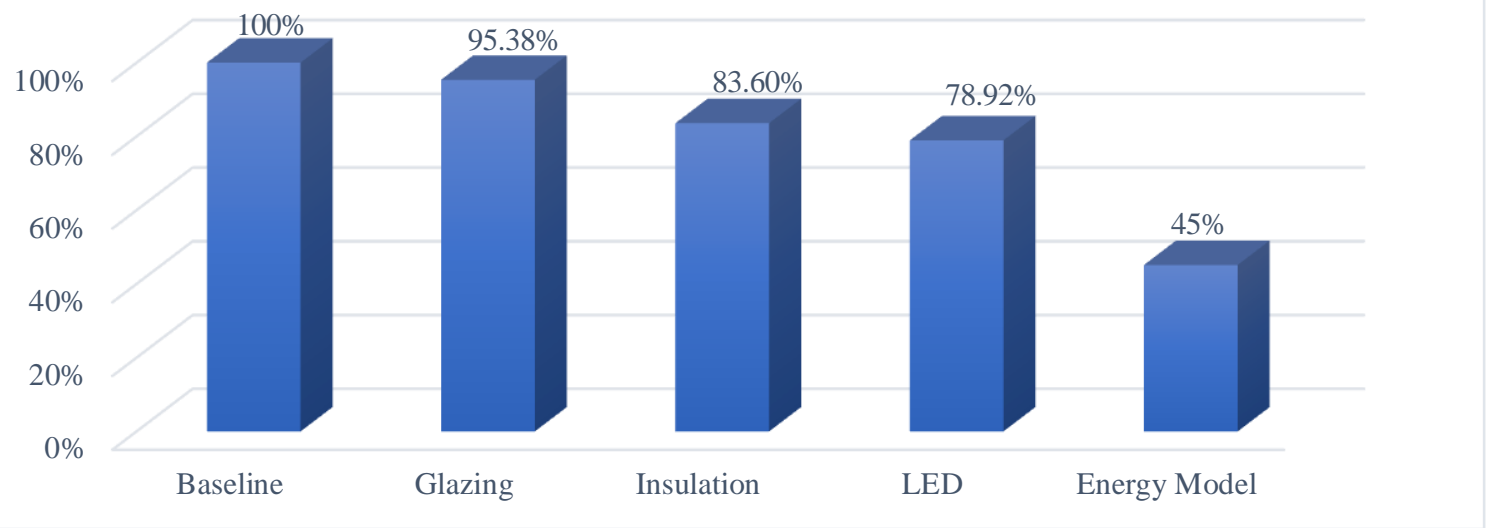

Figure (13): HVAC new use percentage

\subsection{Whole Building Energy Saving}

The previous parameters were investigated also annually on the whole building energy use. Figure (14) illustrates the effect of each modification on the total energy consumption of the building.
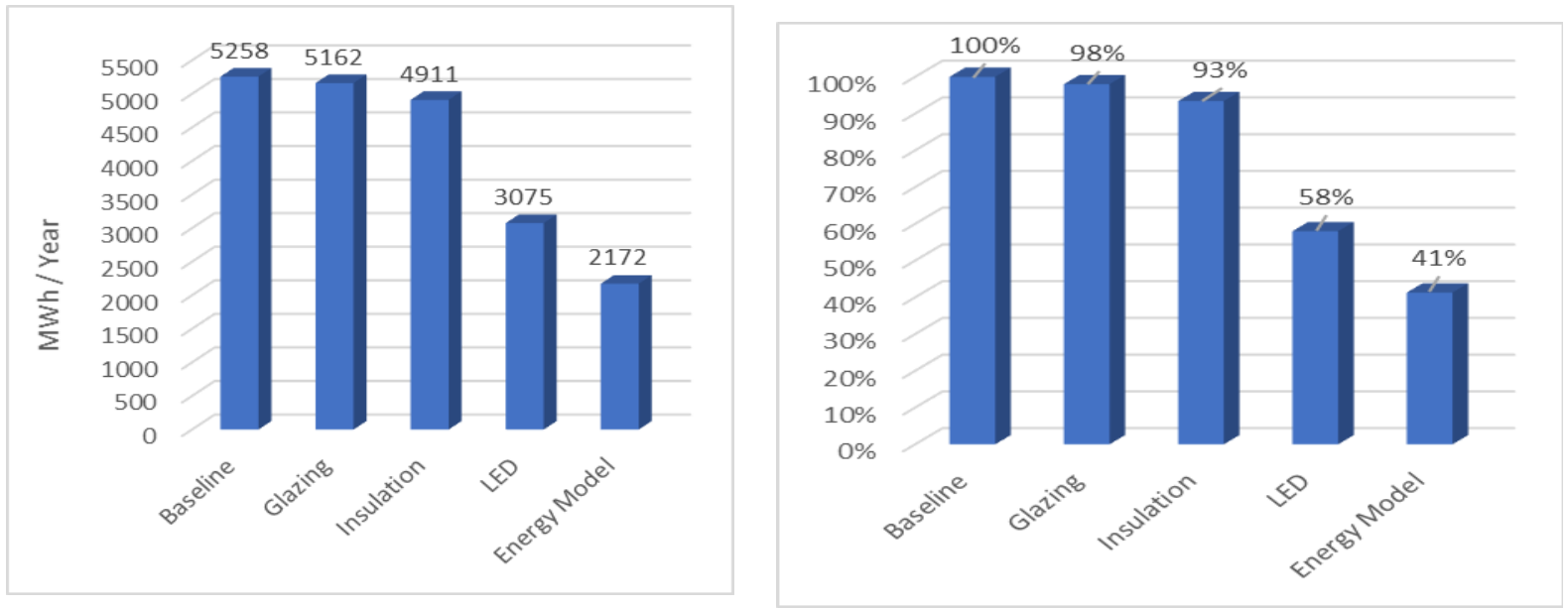

Figure (14) Whole Building Energy Use

The glazing type selection, thermal insulation implementation, LED lighting retrofitting were efficient when adopted to commercial buildings as the graphs show the effect of each parameter alone on both HVAC energy use in Figure (13) and whole building energy use in Figure (14). When these energy saving techniques were combined, significant annual energy savings were achieved in both HVAC energy use and whole building energy use. 
Figure (15) shows the monthly building energy consumption and the effect of each modification on the monthly energy consumption of the whole building.

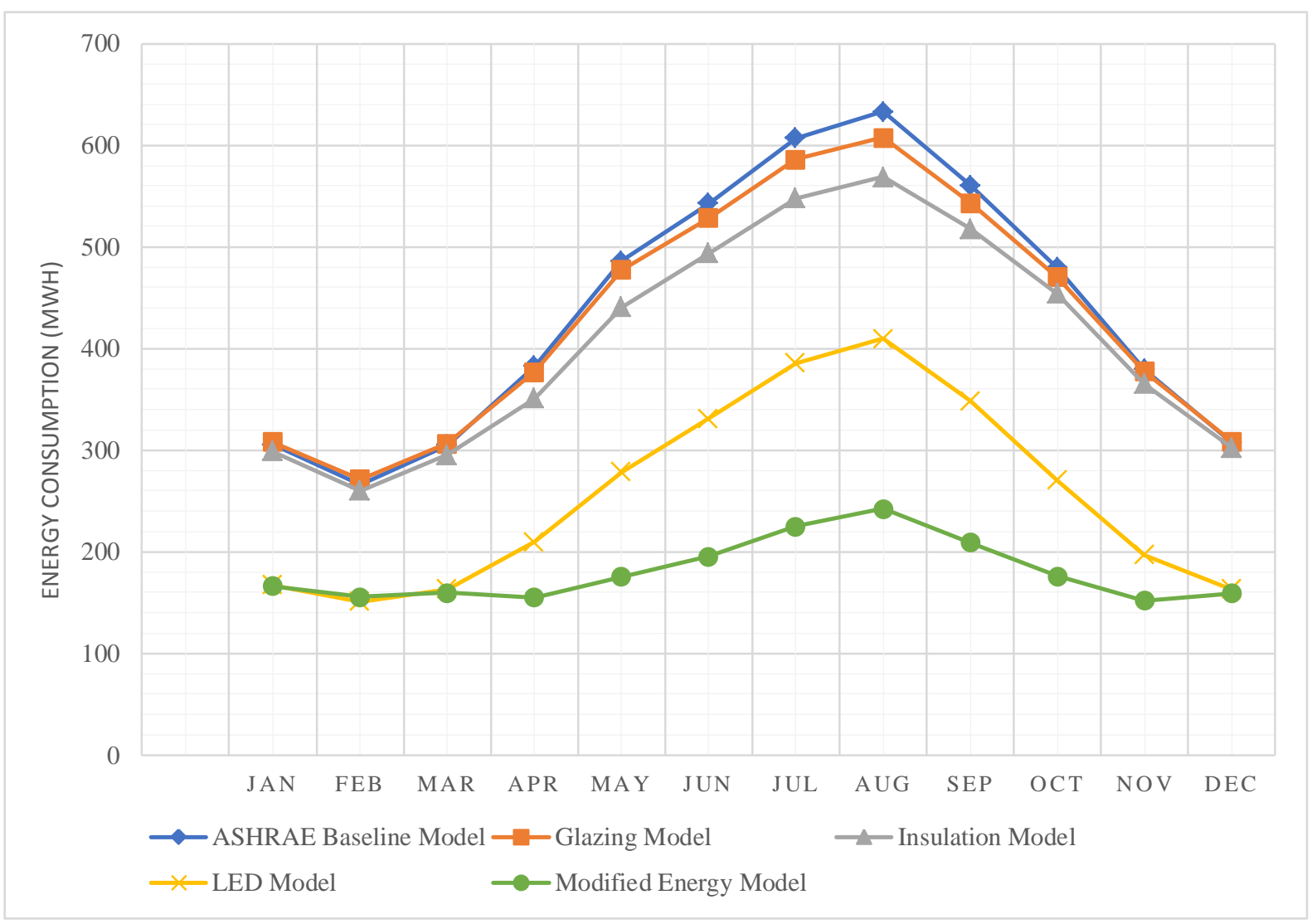

Figure (15): Whole Building Energy Consumption Distribution (MWh)

From Figure (15), the effect of double glazing appears during the summer when the solar heat gains reached its peak. The figure also shows that the effect of thermal insulation was during the summer too, when the outside conditions reached its peak too. The LED model was very efficient to

\section{Conclusion}

1- ASHRAE design conditions must be applied in the Egyptian market as investigated in this study showing $25 \%$ reduction in HVAC energy use and about $12 \%$ in whole building energy use compared to most Egyptian market designing conditions which lead to right-sizing avoiding the oversizing of HVAC systems.

2- Glazing type must be considered as an important parameter in commercial buildings as the study shows $2 \%$ energy savings in whole be used in commercial buildings as it appeared twice in the building, first in the lamp electrical use and then on the heat dissipated by the lamp on the space. Combining the energy saving techniques then showed a great reduction in whole building energy use during the summer especially.

building energy use and about $4.62 \%$ savings in HVAC energy use.

3- Building construction codes are recommended to be applied to all commercial buildings such as adding insulation material to construction as it showed $6.6 \%$ energy saving in whole building energy use and $16.4 \%$ energy savings in HVAC energy use.

4- Lighting Emitting Diodes (LED) available nowadays are efficient in energy saving as it 
showed $42 \%$ in whole building energy use and $21.08 \%$ in HVAC energy use.

5- The simulation showed significant energy savings of approximately $59 \%$ of the whole building energy use with $217 \mathrm{kWh} / \mathrm{m}^{2}$ compared to $525 \mathrm{kWh} / \mathrm{m}^{2}$ in ASHRAE baseline model when applying the energy saving techniques and about 55\% in HVAC energy use.

\section{References}

[1] U.S Energy Information Administration (EIA), Country Analysis Brief: Egypt, May 24, 2018.

[2] Essam E. Khalil, "Energy Efficient Performance of Commercial Buildings in Developing Countries", The Second International Energy 2030 Conference, Abu Dhabi, (2008).

[3] American Society of Heating, Refrigerating and Air-Conditioning Engineers. Advanced Energy Design Guide for Small Hospitals and Healthcare Facilities. American Society of Heating, Refrigerating and Air Conditioning Engineers, Inc., 2009. ISBN 978-1-933742-663.

[4] Egyptian Electricity Holding Company annual report 2016/2017.

[5] [5] Ministry of Economy (2003). Estrategia de Ahorro y Eficiencia Energética en España 2004-2012 en el sector de la edificación.

[6] González, A., Calcedo, J.G.S and Salgado, D.R, "A quantitative analysis of final energy consumption in hospitals in Spain", Sustainable Cities and Society journal, Vol. 36, PP. 169-175, (2018).

[7] Hoyt T. Arens, E. and Zhang, H., "Extending air temperature setpoints: Simulated energy savings and design considerations for new and retrofit buildings", Building and Environment Journal, Vol. 88, PP. 89-96, (2015).

[8] Ahn, B., Jang, C., Yoo, S. and Jeong, H., "Effect of LED lighting on the cooling and heating loads in office buildings", Applied Energy Journal, Vol. 113, PP. 1484-1489, (2014).
Commercial buildings energy saving techniques have a huge impact on energy consumption in Egypt. So, the Egyptian government must start applying the energy saving codes to establish minimum levels of energy performance for unconstructed buildings and auditing for constructed buildings which will lead to decreasing energy and fuel consumption.

[9] Jenkins, D. and Newborough, M. "An approach for estimating the carbon emissions associated with office lighting with a daylight contribution", Applied Energy Journal, Vol. 84, PP. 608-622, (2007).

[10] Sabry, A., Ibrahim, M. and Khalil, E. "Energy Performance Simulation in Residential Buildings", Procedia Engineering journal, Vol. 205, PP. 41874194, (2017).

[11] Karmany, H. M., "Evaluation of Green Building Rating Systems for Egypt", Thesis, American University in Cairo, (2016).

[12] Dutta, A. and Samanta, A., "Reducing cooling load of buildings in the tropical climate through window glazing", Journal of Building Engineering, Vol. 15, PP. 318-327, (2018)

[13] Elharidi, A., Tuohy, P. G. and Teamah, M. A., "The energy and indoor environmental performance of Egyptian Offices", Energy and Building journal, Vol. 158, PP. 431-452, (2017).

[14] Yusoff, W. F. M., Mirrahimi, S., Mohamed, M. F. and Haw, L.C, "The effect of building envelope on the thermal comfort and energy saving for high-rise buildings in hot-humid climate", Renewable and Sustainable Energy Reviews Journal, Vol. 53, PP. 1508-1519, (2016).

[15] AbdulRazek, T. M., "Key performance indicators of energy efficiency for small and medium enterprises", Thesis, Kassel University, Germany, (2014).

[16] ASHRAE Handbook of Fundamentals, American Society of Heating, Refrigerating and Air Conditioning Engineers Inc., (2017). 
[17] EnergyPlus, National Renewable Energy Laboratory (NREL), U.S. Department of Energy, Building Technologies Office (BTO).

[18] AIA, AIA Guidelines for Design and Construction of Hospitals and Health Care Facilities, American Institution of Architects Washington, D.C., (2006).

[19] ASHRAE, Ventilation for Acceptable Indoor Air Quality, ANSI/ASHRAE Standard 62.12016, American Society of Heating, Refrigerating and Air Conditioning Engineers Inc., Atlanta, GA, (2016).

[20] ASHRAE, Ventilation of Healthcare Facilities, ANSI/ASHRAE/ASHE Standard 170-2017, American Society of Heating, Refrigerating and Air Conditioning Engineers Inc., Atlanta, GA, (2017).
[21] MIYAOKA, Y., NAKAYAMA, H., TERANISHI, Y., YOSHIZAWA, N., KABASHIMA, N. and HIROTA, M., "Influence of LED Lamps on Air-conditioning Load and Energy Consumption in Commercial Buildings", 12th IEA Heat Pump Conference, Rotterdam, (2017).

[22] GGHC, Green Guide for Health Care: Best Practices for Creating High-Performance Healing Environments, Version 2.2, (2007).

[23] ASHRAE, Energy Standard for Buildings Except Low-Rise Residential Buildings, ANSI/ ASHRAE/IESNA Standard 90.1-2016. American Society of Heating, Refrigerating and Air Conditioning Engineers, Atlanta, GA, (2016).

[24] Specifications of Heat Insulation Works, Housing and Building National Research Center, (HBRC), Egyptian Ministry of Housing, (2007). 